\title{
Insoluble granite-grit allows broiler chicks to have better growth performance and gut health
}

\author{
Güray Erener ${ }^{1}$, Nuh Ocak ${ }^{1}$, Ali Vaiz Garipoğlu ${ }^{1}$, Ahmet Şahin ${ }^{2}$
}

\author{
${ }^{1}$ Ondokuz Mayis University, Faculty of Agriculture, Department of Animal Science, Samsun, Turkey. \\ ${ }^{2}$ Ahi Evran University, Faculty of Agriculture, Department of Animal Science, Kirsehir, Turkey.
}

\begin{abstract}
The objective of this study was to investigate the effects of insoluble granite-grit on growth performance and gut health status of broiler chicks. One hundred and sixty 14-day-old broiler chicks were allocated to experimental groups control and grit feeding. Each group included 80 birds divided by four replicates, each consisting of 20 birds, 10 males and 10 females. Feed intake, body weight gain, feed conversion ratio, carcass weight, dressing percentage, gut length, abdominal fat pad, and liver, heart, and gizzard weights were determined. Starter diet included $230 \mathrm{~g}^{\mathrm{crude}}$ protein $(\mathrm{CP}) \mathrm{kg}^{-1}$ and 3.15 Mcal metabolizable energy (ME) $\mathrm{kg}^{-1}$ during the days 14 to 21 ; grower diet included $212 \mathrm{~g} \mathrm{CP} \mathrm{kg}^{-1}$ and $3.20 \mathrm{Mcal} \mathrm{ME} \mathrm{kg}$; and finisher diet included $190 \mathrm{~g} \mathrm{CP} \mathrm{kg}^{-1}$ and $3.20 \mathrm{Mcal} \mathrm{ME} \mathrm{kg}^{-1}$. Control birds were fed broiler diets, while grit-fed birds were allowed to consume broiler diets, including 3\% insoluble granite-grit. Grit feeding improved the final body weight (2268 vs. $2336 \mathrm{~g}$ ) with better feed efficiency (2.03 vs. 1.95) and less feed intake (3780 vs. $3764 \mathrm{~g}$ ). Grit feeding increased gizzard weight ( 31.63 vs. 48.00 g) without affecting carcass weight (1643 vs. 1708 g), dressing percentage ( 73.50 vs. $73.60 \%)$, liver weight (42.69 vs. $40.69 \mathrm{~g})$, heart weight (12.00 vs. $11.63 \mathrm{~g}$ ), abdominal fat pad (34.50 vs. $35.38 \mathrm{~g})$, and gut length (229.3 vs. $220.7 \mathrm{~cm})$ of broilers. Grit feeding affects daily gain, feed intake, and feed conversion ratio positively by increasing gizzard development and health.
\end{abstract}

Key Words: grit, gut length, organ weight, poultry

\section{Introduction}

Domestic fowls are different from the other farm animals because they possess various digestive systems, especially the gizzard. The gizzard, which functions as teeth, is an organ found in the digestive tract of broilers. This specialized stomach, constructed of thick muscular walls, is used for grinding up food, often aided by particles of stone or grit. Therefore, the gizzard has a number of important functions, such as aiding digestion by particle size reduction, chemical degradation of nutrients, regulation of feed flow, and quick response to changes in the coarseness of the diet (Moore, 1998; Svihus, 2011). The efficacy of gizzard regarding size and strength depends on the presence of stones, grits, sands, and their small parts in it (Svihus, 2011). Grits can be classified into soluble and insoluble stone kind of objects. Soluble grit sources (limestone and oyster shell) are easily dissolved in the gizzard. Insoluble grit sources (silica, mica, and sand) are

Received May 6, 2016 and accepted August 9, 2016

Corresponding author: gerener@omu.edu.tr

http://dx.doi.org/10.1590/S1806-92902016001100002

Copyright (C) 2016 Sociedade Brasileira de Zootecnia. This is an Open Access article distributed under the terms of the Creative Commons Attribution License (http://creativecommons.org/licenses/by/4.0/), which permits unrestricted use, distribution, and reproduction in any medium, provided the original work is properly cited. non-digestible and are retained in the gizzard (Adeniji and Oyeleke, 2008). In free-range condition, domestic or native fowls pick up stones while scavenging for feed, thus aiding the abrasive activity of the gizzard (Adeniji, 2009, 2010). This activity helps to facilitate the mechanical breakdown of feed materials in the gizzard to be ready for digestion and, afterwards, absorption. Without grit, grinding is less effective. Garipoglu et al. (2006) reported that the granitegrit consumed voluntarily by broilers increased gut length and empty gizzard weight without affecting the growth performance of broilers. Recently, Idachaba et al. (2013a,b) reported that dietary grit improved feed utilisation in broilers. On the contrary, birds reared under intensive management conditions have no access to such stones and hence their ability to digest the high fibre content of their diets is very low (Adeniji and Oyeleke, 2008). There is a possibility that incorporation of grits (stones) into the diet of the intensively reared birds may increase animal welfare since it will give them the opportunity to have what is normally available by nature.

Broiler chickens are fed diets containing high energy and low fibre in mash or pellet form. This results in undeveloped or atrophic gizzard (Sacranie et al., 2012). Due to the reported improvements in nutrient availability when structural components that stimulate gizzard development have been added to the diet, it is recommended to include 
at least 20 to $30 \%$ cereal particles larger than $1 \mathrm{~mm}$ in size, or to include at least 3\% coarse fibres such as oat hulls in the diet (Svihus, 2011). Even though choice feeding and whole-grain feeding methods have been used to give birds more freedom and better health (Olver and Jonker, 1997; Banfield and Forbes, 2001; Rutrowski and Wiaz, 2001; Plavnik et al., 2002; Erener et al., 2003; Garipoglu et al., 2006), there is still the need to study further, especially by using dietary tools to improve animal welfare through helping gizzard development and functioning. However, there is no newly published literature related to grit feeding. In the free-range poultry production system, birds have the opportunity to take sand, grit, or stones from the ground, but this is not possible in the intensive poultry production system in which all diets are of the best quality with respect to energy and protein without including any bulky or hard objects. Therefore, in the current study, insoluble grit was supplemented to mash diet to test the possible beneficial effects on growth performance and gut health.

\section{Material and Methods}

The management of broiler chicks and all procedures in the study were performed according to the Animal Experimental Guidelines for local Ethical Committee of our university. Experimental diets were starter, grower, and finisher, with all of them in mash form. A starter diet was offered to birds during the period of 14-21 d and included $230 \mathrm{~g}$ crude protein (CP) and 3.15 Mcal metabolizable energy (ME) $\mathrm{kg}^{-1}$; a grower diet was offered from 22-35 d and included $212 \mathrm{~g} \mathrm{CP}$ and $3.20 \mathrm{Mcal} \mathrm{ME} \mathrm{kg}^{-1}$; and a finisher diet was offered from 36-42 $\mathrm{d}$ and included $190 \mathrm{~g} \mathrm{CP}$ and 3.20 Mcal ME kg-1 (Table 1). The control group had these diets while grit-fed birds were given diets including 3\% insoluble granite-grit with 1-mm particle size (Garipoglu et al., 2006). Granite-grit was obtained from the Granite Mill in Ordu Province of Turkey. Experimental granite-grit included $70.47 \% \mathrm{SiO}_{2}, 14.47 \% \mathrm{Al}_{2} \mathrm{O}_{3}, 4.11 \% \mathrm{~K}_{2} \mathrm{O}, 3.48 \%$ $\mathrm{Na}_{2} \mathrm{O}, 1.99 \% \mathrm{CaO}, 1.78 \% \mathrm{FeO}, 1.57 \% \mathrm{Fe}_{2} \mathrm{O}_{3}, 0.88 \% \mathrm{MgO}$, $0.74 \% \mathrm{H}_{2} \mathrm{O}, 0.20 \% \mathrm{TiO}_{2}, 0.19 \% \mathrm{P}_{2} \mathrm{O}_{5}$, and $0.12 \% \mathrm{MnO}$ (Yüksel, 2003).

Before the experiment (up to $14 \mathrm{~d}$ of age), all chicks were fed on a starter diet containing $230 \mathrm{~g} \mathrm{CP}$ and 3.15 Mcal ME kg-1. This study was initiated at 14 days of age, since in our previous study (Garipoglu et al., 2006), broilers had a higher voluntary intake of granite-grit at 15 to $21 \mathrm{~d}$ of age than at 7 to $14 \mathrm{~d}$ of age. At the beginning of the experiment, 160 broiler chicks (Ross 308) were divided as control group and grit-fed group with equal body weight and an equal number of males and females. Each group consisted of four replicates, each one including 10 females and 10 males. Feed and water were provided ad libitum. Vaccination and other management practices were carried out appropriately. The grit was not a part of the formulated diet, as it was extraneously added to the diet. The experiment lasted 28 days. Body weight gain and feed intake were recorded weekly while mortality was recorded daily. At $42 \mathrm{~d}$ old, two females and two males from each replicate were humanly slaughtered to determine carcass weight, dressing percentage, abdominal fat pad, weights of liver, heart, and gizzard, and gut length.

All statistical analysis was performed by means of SPSS 11.0 for Windows software (SPSS Inc., NY, USA). Levene's test and Shapiro-Wilk's test were initially used for equality of variance and for normality assumption, respectively, of the traits (body weight, total gain, feed intake, etc.) for the control and insoluble granite-grit groups $(\mathrm{P}>0.05)$. Then, Student $t$-test was used to determine the differences between the control and insoluble granite-grit groups. Finally, the findings were expressed as sample size (n) mean with standard deviation values. A P-value of less than 0.05 was considered statistically significant (SPSS, version 11.0).

Table 1 - Ingredients and composition of broiler diets

\begin{tabular}{lccc}
\hline & Starter & Grower & Finisher \\
\hline Ingredient $\left(\mathrm{g} \mathrm{kg}^{-1}\right.$ as fed $)$ & & & \\
Maize, yellow & 355.5 & 330.4 & 256.8 \\
Soybean meal $\left(480 \mathrm{~g} \mathrm{CP} \mathrm{kg}^{-1}\right)$ & 275.3 & 204.5 & 171.5 \\
Sunflower meal $\left(350 \mathrm{~g} \mathrm{CP} \mathrm{kg}^{-1}\right)$ & 110.0 & 150.0 & 111.5 \\
Wheat & 99.0 & 130.0 & 330.0 \\
Wheat bran & - & 38.0 & - \\
Meat-bone meal & 64.4 & 56.0 & 49.2 \\
Vegetable oil & 73.7 & 85.0 & 73.6 \\
Limestone & 13.6 & - & - \\
Premix & 3.5 & 3.5 & 3.1 \\
Sodium chloride & 3.0 & 2.5 & 2.5 \\
L-lysine & 0.4 & - & 0.1 \\
DL-methionine & 1.6 & 0.1 & 1.7 \\
Chemical composition $\left(\mathrm{g} \mathrm{kg}^{-1}\right.$ as fed) & & & \\
ME (Mcal/kg of diet) & 3.15 & 3.20 & 3.20 \\
Crude protein & 230.0 & 212.0 & 189.8 \\
Calcium & 15.0 & 9.0 & 8.0 \\
Available phosphorus & 5.0 & 4.7 & 3.9 \\
Lysine & 12.0 & 10.0 & 8.5 \\
Methionine & 5.6 & 4.0 & 5.2 \\
Methionine + cysteine & 9.3 & 7.6 & 8.4 \\
Sodium chloride & 3.4 & 2.9 & 2.9 \\
\hline
\end{tabular}

$\mathrm{CP}$ - crude protein; ME - metabolizable energy.

${ }^{1}$ Provides per kilogram of diet: Mn, $80 \mathrm{mg}$; Zn, $60 \mathrm{mg}$; Fe, $60 \mathrm{mg}$; Cu, $5 \mathrm{mg}$; Co, $0.2 \mathrm{mg}$; I, $1 \mathrm{mg}$; Se, $0.15 \mathrm{mg}$; choline chloride, $200 \mathrm{mg}$; vitamin A, 12,000 IU; vitamin D3, 2,400 IU; vitamin E, $50 \mathrm{mg}$; vitamin $\mathrm{K} 3,4 \mathrm{mg}$; vitamin B1, $3 \mathrm{mg}$; vitamin B2, $6 \mathrm{mg}$; niacin, $25 \mathrm{mg}$; calcium-D-pantothenate, $10 \mathrm{mg}$; vitamin $\mathrm{B} 6,5 \mathrm{mg}$; vitamin $\mathrm{B} 12$, $0.03 \mathrm{mg}$; D-biotin, $0.05 \mathrm{mg}$; and folic acid, $1 \mathrm{mg}$. 


\section{Results and Discussion}

During the experimental period, there was no mortality in the control and grit-fed groups, indicating that grit does not affect the general health status of birds. Grit-feeding positively affected daily weight gain, feed intake, and feed conversion ratio (Table 2). At the first week of the experiment, grit-fed birds decreased feed intake by about $10 \mathrm{~g}(\mathrm{P}<0.01)$ that led to a better feed efficiency $(\mathrm{P}<0.05)$ and approximately $25 \mathrm{~g}$ more body weight gain $(\mathrm{P}<0.05)$. This decrease in feed intake $(\mathrm{P}<0.05)$ continued in the following week without affecting growth performance. At $35 \mathrm{~d}$ old, grit-fed birds were nearly $40 \mathrm{~g}$ heavier than the control birds $(\mathrm{P}<0.01)$. These significant differences continued up to the end of the study $(\mathrm{P}<0.05)$, i.e., gritfed birds gained $70 \mathrm{~g}$ more than control with better feed efficiency.

Grit-fed birds consumed less amounts of energy and protein, but had better growth performance than control birds with respect to body weight, body gain, feed intake, and feed conversion ratio. The presence of grit, in 1-mm medium size, in current mash diet, helped birds to grind food into smaller particles; therefore, grit-feeding could lead to enhanced growth performance. Contrary to the results of the present study, in the previous study (Garipoglu et al., 2006), the granite-grit consumed by broilers voluntarily increased gut length and empty gizzard weight without affecting the growth performance of broilers. On the basis of the results of these two studies, it can be said that insoluble granitegrit should be added compulsorily to the diet of birds.

The presence of grit in mash form may cause need of extra energy or extra work to get rid of the granite-grit from the body. This extra energy was used for excretion rather than to enhance growth. Since grit-fed birds worked to get rid of granite-grit, the grit in mash feed may cause less amount of mechanical digestion. In our study, the crude ash and insoluble grit with HCL ash contents of faeces were not analyzed. As reported previously, they were 15.91 and 17.96 in control, and 0.84 and $4.22 \%$ in grit treatment, respectively (Garipoglu et al., 2006). These results showed that dietary grit was removed from the body of birds in undissolved form, supporting the idea of extra energy loss for excretion of insoluble grit. This was supported by the fact that the current broiler chicks did not show any strong appetite for the grit as seen in lower intake rate. According to a study of house sparrows, as daily grit dose increased, house sparrows on a hard diet had more small $(0.2-0.4 \mathrm{~mm})$ and medium size $(0.6-0.8 \mathrm{~mm})$ grit in their gizzards than house sparrows on a soft diet. Since birds eating soft foods require less grit, it may be that grit retention is a more random process for such birds than it is for birds eating hard foods (Best and Stafford, 2015). In the current study, mash diet should be considered as soft diet and birds tried to get rid of 1-mm sized grit from their gut. The physical structure of diet has been recognized as an important factor to affect broiler growth performance,

Table 2 - Effect of grit-feeding on growth performance of broiler chicks ( $\left.\mathrm{g} \mathrm{bird}^{-1}\right)$

\begin{tabular}{|c|c|c|c|c|c|}
\hline \multirow{2}{*}{ Item } & \multicolumn{2}{|c|}{ Control } & \multicolumn{2}{|c|}{ Grit-feeding } & \multirow{2}{*}{ P-value } \\
\hline & Mean & Standard deviation & Mean & Standard deviation & \\
\hline Initial body weight & 402.92 & 4.87 & 406.15 & 2.35 & 0.227 \\
\hline \multicolumn{6}{|l|}{ At $21 \mathrm{~d}$ old } \\
\hline Body weight & 736.71 & 4.41 & 766.10 & 20.08 & 0.029 \\
\hline Total gain & 333.79 & 1.87 & 359.95 & 18.88 & 0.033 \\
\hline Feed intake & 497.60 & 0.91 & 487.30 & 1.97 & $<0.001$ \\
\hline Feed conversion ratio ( $\mathrm{g}$ feed:g gain) & 1.49 & 0.01 & 1.36 & 0.07 & 0.011 \\
\hline \multicolumn{6}{|l|}{ At $28 \mathrm{~d}$ old } \\
\hline Body weight & 1179.83 & 10.81 & 1196.58 & 33.07 & 0.373 \\
\hline Total gain & 776.92 & 15.53 & 790.43 & 31.05 & 0.466 \\
\hline Cumulative feed intake & 1325.10 & 5.82 & 1309.80 & 9.59 & 0.034 \\
\hline Feed conversion ratio ( $\mathrm{g}$ feed:g gain) & 1.71 & 0.04 & 1.66 & 0.06 & 0.205 \\
\hline \multicolumn{6}{|l|}{ At $35 \mathrm{~d}$ old } \\
\hline Body weight & 1840.00 & 11.04 & 1885.58 & 19.61 & 0.007 \\
\hline Total gain & 1437.08 & 10.43 & 1479.43 & 17.36 & 0.006 \\
\hline Cumulative feed intake & 2552.17 & 12.73 & 2532.80 & 13.39 & 0.081 \\
\hline Feed conversion ratio ( $\mathrm{g}$ feed:g gain) & 1.78 & 0.01 & 1.71 & 0.02 & 0.002 \\
\hline \multicolumn{6}{|l|}{ At 42 d old } \\
\hline Body weight & 2267.67 & 37.17 & 2336.33 & 27.38 & 0.025 \\
\hline Total gain & 1864.75 & 41.51 & 1930.18 & 25.11 & 0.036 \\
\hline Cumulative feed intake & 3779.92 & 7.53 & 3763.63 & 8.27 & 0.027 \\
\hline Feed conversion ratio ( $\mathrm{g}$ feed:g gain) & 2.03 & 0.04 & 1.95 & 0.03 & 0.024 \\
\hline
\end{tabular}


especially feed efficiency, in the poultry industry (Xu et al., 2015). Current finely ground mash diet might have already been of the required size, possessing the adequate surface area to allow penetration of digestive enzymes for better nutrient utilisation. Furthermore, current grit addition to mash diet might have increased this process, as evidenced by a slight but significant increase in growth performance. Idachaba et al. (2013b) used 2, 4, 6, 8, and $10 \mathrm{~g}$ granitegrit per bird per month in one-week-old broiler chicks and concluded that $10 \mathrm{~g}$ granite-grit was beneficial to broilers, as it allows for efficient nutrient utilisation. In the current study, birds consumed nearly $113 \mathrm{~g}$ granite-grit monthly during the period of 14-42 $\mathrm{d}$ old. This amount was ten times more than that used by Idachaba et al. (2013b). In addition, the broilers in our study were one week older than those in the study of Idachaba et al. (2013b). These results support the idea that the age of the bird influences the intake of granite-grit (Garipoglu et al., 2006). Conversely, Rowland and Hooge (1980) added 6\% sand to broiler starter diet and found out that this inclusion rate improved feed utilisation and caloric efficiency with economic advantage, supporting our findings on growth performance. Whole grain feeding in broiler chicks lowered growth because of the absence of grit source in the diet (Bennett et al., 1995). In contrast, Svihus et al. (1997) found out that barley-feeding with or without grit did not affect body weight, feed conversion ratio, and gizzard weight.

There were significant differences with respect to relative full gut length and gizzard weight $(\mathrm{P}<0.05)$ without affecting carcass weight, dressing percentage, full gut weight, and abdominal fat pad weight $(\mathrm{P}>0.05)$ (Table 3 ). The gizzard weight of grit-fed birds was higher than those of control birds $(\mathrm{P}<0.05)$. The heavier gizzard weight in grit-fed birds might be attributable to the well- worked muscles in the gizzard. The hardworking gizzard helps refine feed more and allows for a more efficient use of the upper side of the intestine. As known, absorption of nutrients and growth performance are affected by feed transit time (Van der Klis and Voorst, 1993; Uni et al., 1995). This result is in agreement with that of Jones and Taylor (1999). In addition, Y1ldiz et al. (2001) fed broiler chicks with grit sized 1-2 mm (2-4.5 $\left.\mathrm{g} \mathrm{bird}^{-1}\right)$ and found out that the muscular structure of gizzard increased by dietary grit. The heavier gizzard supports the idea of a hardworking gizzard (Svihus, 2011). The working ability of the gizzard depends on the size of grit and its presence in the gizzard. Moore (1998) reported that the gizzard worked hard when gizzard stones were in large size and higher amount.

The foraging of stone and sands from the ground is a natural behaviour for fowl. In the present study, we thought to give animals this foraging opportunity to behave naturally to get rid of the negative consequences of intensive farming condition. Administering grit mixed in broiler diet did not cause any extra labour or expenses. In addition, this natural behaviour is a kind of enrichment for animal welfare through dietary addition of grit to mash diet. Granite-grit may also be assessed in pellet. Actually, high-nutrient density poultry feeds with lower fibre content cause laziness in the gizzard and reduces muscle activities (Forbes and Covasa, 1995). These feeds go through the digestive system and reach the intestine without mixing enough digestive enzymes due to insufficient surface area, leading to increased pathogenic bacteria species on the upper side of the intestine (Svihus, 2011; Sacranie et al., 2012) and vulnerability to infections (Cumming, 1992). Based on these pieces of information and suggestions, as well as our results in the present and previous studies (Garipoglu et al., 2006), it can be said that feeding broilers a diet supplemented with insoluble granite-

Table 3 - Effects of grit-feeding on some carcass traits of broilers

\begin{tabular}{|c|c|c|c|c|c|}
\hline \multirow{2}{*}{ Item } & \multicolumn{2}{|c|}{ Control } & \multicolumn{2}{|c|}{ Grit-feeding } & \multirow{2}{*}{ P-value } \\
\hline & Mean & Standard deviation & Mean & Standard deviation & \\
\hline \multicolumn{6}{|l|}{ Absolute weight $\left(\mathrm{g} \mathrm{bird}^{-1}\right)$} \\
\hline Slaughter & 2234.69 & 222.29 & 2321.56 & 172.93 & 0.227 \\
\hline Liver & 42.69 & 4.96 & 40.69 & 3.72 & 0.207 \\
\hline Heart & 12.00 & 1.41 & 11.63 & 1.54 & 0.479 \\
\hline Gizzard & 31.63 & 1.93 & 48.00 & 2.90 & $<0.001$ \\
\hline \multicolumn{6}{|l|}{ Relative weight (g $100 \mathrm{~g} \mathrm{BW}^{-1}$ ) } \\
\hline Carcass & 73.50 & 1.89 & 73.60 & 1.68 & 0.881 \\
\hline Gizzard & 1.43 & 0.14 & 2.07 & 0.14 & $<0.001$ \\
\hline Abdominal fat & 1.55 & 0.22 & 1.53 & 0.24 & 0.809 \\
\hline \multicolumn{6}{|l|}{ Length of gut } \\
\hline Absolute $\left(\mathrm{cm} \mathrm{bird}{ }^{-1}\right)$ & 229.31 & 15.03 & 220.69 & 14.04 & 0.104 \\
\hline
\end{tabular}

BW - body weight. 
grit in intensive poultry farm has advantages in the freerange production system.

\section{Conclusions}

Diet supplemented with insoluble granite-grit improves gizzard development and health in broilers fed a high energetic diet with lower cellulose content, preventing the gizzard from atrophy and compensating for the natural foraging instinct. Therefore, insoluble granite-grit feeding for broilers in the grower and finisher phases improves animal performance by increasing gizzard development and health.

\section{Acknowledgments}

The authors gratefully acknowledge the support of the staff and facilities of the Ondokuz Mayis University, Faculty of Agriculture.

\section{References}

Adeniji, A. A. and Oyeleke, M. M. 2008. Effects of dietary grit fed on the utilization of rumen content by pullet chicks. Journal of Applied Sciences Research 4:1257-1260.

Adeniji, A. A. 2009. Effects of dietary grit inclusion on the utilization of palm kernel cake by pullet chicks. Animal Nutrition and Feed Technology 9:29-36.

Adeniji, A. A. 2010. Effects of dietary grit inclusion on the utilization of rice husk by pullet chicks. Tropical and Subtropical Agroecosystems 12:175-180.

Banfield, M. J. and Forbes, J. M. 2001. Effects of whole wheat dilution v. substitution on coccidiosis in broiler chickens. British Journal of Nutrition 86:89-95.

Bennett, C. D.; Classen, H. L. and Riddell, C. 1995. Live performance and health of broiler chickens fed diluted with whole or crumbled wheat. Canadian Journal of Animal Science 75:611-614.

Best, B. L. and Stafford, T. R. 2015. Influence of daily grit consumption rate and diet on gizzard grit counts. The Journal of Wildlife Management 66:381-391.

Cumming, R. B. 1992. p.627-630. The advantage of free-choice feeding for village chickens. In: Proceedings of the 19th World Poultry Congress, The Netherlands.

Erener, G.; Ocak, N.; Ozturk, E. and Ozdas, A. 2003. Effect of different choice feeding methods based on whole wheat on performance of male broiler chickens. Animal Feed Science and Technology 106:131-138

Forbes, J. M. and Covasa, M. 1995. Application of diet selection by poultry with particular reference to whole cereals. World's Poultry Science Journal 51:149-165.
Garipoglu, A. V.; Erener, G. and Ocak, N. 2006. Voluntary intake of insoluble granite-grit offered in free choice by broilers: Its effect on their digestive tract traits and performances. Asian-Australasian Journal of Animal Science 19:549-553.

Idachaba, C. U.; Abeke F. O.; Olugbemi, T. S.; Anoh, K. U. and Ademu, L. A. 2013a. Effects of graded levels of stone grit on the utilization of rice offal based diets by broiler chickens. International Journal of Applied Research and Technology 2:125-131.

Idachaba, C. U.; Abeke, F. O.; Olugbemi, T. S. and Ademu, L. A. 2013b. Influence of granite grit on nutrient digestibility and haematological parameters of broiler chickens fed rice offal based diets. Pakistan Journal of Biological Sciences 16:1061-1064.

Jones, G. P. D. and Taylor, R. D. 1999. Performance and gut characteristics of grit-fed broilers. Proceedings of the Australian Poultry Science Symposium 11:57-60.

Moore, S. J. 1998. Use of an artificial gizzard to investigate the effect of grit on the breakdown of grass. Journal of Zoology 246:119-124.

Olver, M. and Jonker, A. 1997. Effect of choice feeding on the performance of broiler. British Poultry Science 38:571-576.

Plavnik, I.; Macovsky, B. and Sklan, D. 2002. Effect of feeding whole wheat on performance of broiler chickens. Animal Feed Science and Technology 96:229-236.

Rowland, L. O. Jr. and Hooge, D. M. 1980. Effect of dietary sand on the performance of young broiler chickens. Poultry Science 59:1907-1911

Rutrowski, A. and Wiaz, M. 2001. Effect of feeding whole or ground wheat grain on the weight of the gizzard and $\mathrm{pH}$ of digest in broiler chickens. Journal of Animal and Feed Sciences 10:285-289.

Sacranie, A.; Svihus, B.; Denstadli, V.; Moen, B.; Iji, P. A. and Choct, M. 2012. The effect of insoluble fiber and intermittent feeding on gizzard development, gut motility, and performance of broiler chickens. Poultry Science 91:693-700.

Svihus, B.; Herstad, O.; Newman, C. W. and Newman. R. K. 1997. Comparison of performance and intestinal characteristics of broiler chickens fed on diets containing whole, rolled or ground barley. British Poultry Science 38:524-529.

Svihus, B. 2011. The gizzard: function, influence of diet structure and effects on nutrient availability. World's Poultry Science Journal 67:207-224.

Uni, Z.; Noy, Y. and Sklan. D. 1995. Posthatch changes in morphology and function of the small intestines in heavy- and light-strain chicks. Poultry Science 74:1622-1629.

Y1ldı, B.; Yıldız, H. and Bahadır, A. 2001. The effects of physical texture of feed and feeding regime on the gizzards of broilers. Turkish Journal of Veterinary Animal Science 25:295-300 (in Turkish).

Yüksel, Y. 2003. Personnel communication with geological engineer in the Directorate of State Water Affairs of Ordu Province, Turkey.

Van der Klis, J. D. and Van Voorst, A. 1993. The effect of carboxymethyl cellulose (a soluble pollysaccharide) on the rate of marker excretion from gastrointestinal tract of broilers. Poultry Science 72:503-512.

Xu, Y.; Stark, C. R.; Ferket, P. R.; Williams, C. M. and Brake, J. 2015. Effects of feed form and dietary coarse ground corn on broiler live performance, body weight uniformity, relative gizzard weight, excreta nitrogen and particle size preference behaviors. Poultry Science 94:1549-1556. 